Gonda Zsuzsa ${ }^{1}-$ Molnár Gábor Tamás ${ }^{2}$

1 MTA-ELTE Digitális Írástudás és Irodalomoktatás Kutatócsoport

2 MTA-ELTE Digitális Írástudás és Irodalomoktatás Kutatócsoport

\title{
Irodalomértés és kreatív szövegfeldolgozás a digitális magyarórán
}

Az információs technológia digitális átalakulása az oktatási rendszer egészét mélyen érinti. Az átalakulás egyes következményei általánosak, például az infrastruktúrára, a tantárgyi hálóra és az oktatásmódszertanra vonatkoznak. Az információhoz való hozzáférés megváltozása szinte minden tanulási területen fölveti az éló tanári magyarázatra, a tankönyvre és az önálló otthoni tanulásra alapozott oktatási kultúra átgondolásának igényét. Azonban feltehetóleg az összes tantárgy közül az irodalom viszonyul a legkomplexebb módon a digitális átalakuláshoz.

\section{Bevezetés, elméleti áttekintés}

A mennyiben „digitális írástudásnak” nevezzük azt a tudás- és készségegyüttest, amely lehetővé teszi az új kommunikációs technológiák kezelését és az általuk átalakított társadalmi érintkezésben való részvételt, akkor a hagyományosan az írástudáshoz kapcsolt jelentésmező újragondolása is elkerülhetetlen. Felfoghatjuk „képességek olyan összetett és dinamikus hálózataként, amelyet bonyolult, feszültségekkel és új lehetőségekkel egyaránt jellemezhető kapcsolatok kötnek az írástudás hagyományos válfajaihoz" (Bengi, 2018. 35.). Ráadásul ennek a jelentésmezőnek az irodaloméval való átfedése nem tagadható, és ez az átfedés mindkét fogalom történeti változékonyságára is figyelmeztet.

Kutatócsoportunk egyik módszertani célkitüzése, hogy összekapcsoljuk az irodalomés a médiatudomány szakmai hagyományából eredő megfontolásokat a korszerü pedagógiai és tanulástudományi megközelítésmódokkal. Kérdéseink az irodalom mibenlétére, az irodalomnak a digitális közegben való viselkedésére is vonatkoznak; így áttételesen arra is, hogy mit érthetünk egyáltalán irodalmon egy túlnyomórészt digitalizált kulturális világban. A tanulmány második felében egy gyakorlati osztálytermi kísérlet eredményeit mutatjuk be, előtte azonban fontos összefoglalni a kutatás kidolgozását vezérlő elméleti problémákat, valamint a témára vonatkozó szakirodalomból adódó hipotéziseket és értelmezési ajánlásokat.

Az irodalom és a digitális világ viszonyát elemző szakemberek aligha tudják elkerülni a médiakonkurrencia, a médiumok közötti versengés és ezzel áttételesen a figyelemszóródás problémáját. A F. Kittler elméleti kutatásaira visszavezethető történeti modellben a modern médiatörténet az irodalom kiváltságos helyzetének visszaszorulásaként írható le. Miközben az irodalmi írás elveszíti az 1800 körül magának kivívott vezető szerepét, 
mégis fokozott médiaelméleti figyelem tárgya marad, amennyiben - az érzékelhető információt közvetlenül tároló médiumokkal szemben - az írás áttételessége, közvetettsége alkalmat ad magának a közvetítésnek a reflexiójára (Dörr és Goebel, 2018. 10.). Amenynyiben a digitális átalakulásra mint újabb átfogó médiatörténeti fordulatra tekintünk, nyitott kérdésként merül föl, hogy az irodalom miként képes megújulni és megőrizni ezt a korábbi speciális funkcióját. Feltételezzük, hogy ez nem kis részben az irodalomtanítás módszertani kultúráján múlik.

„A digitális fordulat kihívást jelent, sőt nem kedvez az irodalom közvetítésének. Így még ha a nem-olvasás helyébe a szöveges tartalmak másként-olvasása lép is, ez továbbra sem teszi megnyugtatóan lezárhatóvá az irodalom digitális világban elfoglalt helyére vonatkozó kérdést” (Bengi, 2018. 36.). A nem-olvasás és a másként-olvasás kérdése a digitalizációhoz kapcsolódó viták állandó témája. A digitális közeg és az irodalmi olvasás összeférhetetlenségének kérdése legalább N. Carr 2008-as cikke óta (Elbutit-e a Google?) visszatér a közéleti és szaktudományos vitákban. Carr (2008) szerint az állandó összekötöttség és a könnyen elérhető nagy mennyiségü információ lehetetlenné teszi a lineáris gondolatmenetekre vagy mély átélést igénylő szövegekre való odafigyelést, és ezzel a nyomtatott szövegekre épülö modern individuumot is létében fenyegeti. A Shirky által képviselt ellentétes álláspont az online kommunikáció demokratikusságát állítja szembe az irodalmi kánonok hierarchikusságával (vö. Hammond, 2017. 6-7.). Noha ezek a megnyilatkozásuk modalitásukban ellentétesek (technofóbia és technofília ellentétét jelenítik meg), annyiban mégis közösek, hogy a digitális közegek és az irodalom összeférhetetlenségét állítják.

N. K. Hayles kritikájában rámutat, hogy Carr összefoglalói nem mindig pontosan adják vissza az idézett kutatások eredményeit, és ebből óvatosan derülátó következtetésekre jut (Hayles, 2010. 71.). Hayles a nyomtatott könyv és a digitális multimédia kizáró ellentéte helyett olvasásmódokról beszél, amelyek különböző módon érvényesülnek az eltérő közegekben. Eszerint a modern irodalomtudományban optimálisnak tekintett szoros olvasás mellett létezik a linkek és információk között ugráló hiperolvasás, valamint a gépi olvasás, amely az elmúlt évtizedekben eleinte észrevétlenül, újabban viszont nyíltan forradalmasította a szövegfeldolgozás tudományos módszertanát a bölcsészettudományban. Hayles (2010. 78.) a három olvasásmód „termékeny összjátékát” szorgalmazza az irodalom feldolgozásában. Példái között pedig expliciten a tanításra vonatkozót is találunk: A. Liu Irodalom + címü tanítási projektjében a Rómeó és Júliát dolgozták föl a hallgatók kollaboratívan, a Facebook felületét használva föl a szereplök viszonyrendszerének feltérképezésére. A bemutatás szerint ez a módszer a diákoktól „értelmezői döntéseket" (Hayles, 2010. 76.) is igényelt, amennyiben az új közegben való megjelenítéshez ki kell választani a releváns eseményeket és szövegrészeket a drámából.

Hayles olvasástipológiája talán egy ponton finomításra is szorulhat, amennyiben a szoros olvasásnak az angol-amerikai irodalomtudományban kidolgozott fogalma nem egészen azonosítható a nagy terjedelmü szövegek elmélyült olvasásának képességével és kulturális szokásával. A Carr által kirobbantott vitában fölmerült egyik kérdés az volt, hogy az internet korában ki képes végigolvasni a Háború és békét. A Tolsztoj-regény végigolvasása természetesen kitartó odafigyelést és elmélyülést igényel, mégsem biztos, hogy az alapvetően a polgári szabadidős kultúrához kapcsolódó olvasási szokásokat érdemes azonosítani egy irodalomtudományi irányzattól eredő, ráadásul módszertani elöírásokat is tartalmazó fogalommal. A klasszikus regényolvasásról szólva inkább a belefeledkező/belemerülö (immersive) olvasás képességéről van szó (Vischer Bruns, 2010. 51skk.), amely lehetővé teszi a képzeleti viszonyulást egy elbeszélt világhoz, és ezzel megalapozza a szöveg poétikai, világnézeti, nyelvi jellegzetességeire vonatkozó kritikai reflexiót. A szoros olvasás mint tudatos értelmezői stratégia inkább a következő fázisban jelentkezhet, az egyes passzusokra irányuló közelebbi elemzés során. 
A szoros olvasás és a digitális közegek összekapcsolása mégsem egészen véletlenszerü és rendre vissza is tér a téma újabb szakirodalmában. A. Hammond, az Irodalom a digitális korban címü monográfia szerzője is rámutat az Új Kritikában kidolgozott módszer médiatörténeti jelentőségére. Szerinte a modern irodalomtudomány kialakulása nem elválasztható a távközlés modern fejlődésétől, a szoros olvasás metodikáját pedig már éppen a felgyorsult modern társadalom és a megszaporodó médiumok miatti aggodalom hívta elö. „Az Új Kritikát arra a hitre alapozták, hogy az irodalmi nyelv eltér az írott nyelv egyéb formáitól [...], és éppen emiatt az irodalmi nyelv az irodalomtudomány voltaképpeni fókuszpontja. Ebből a célból szorgalmazták az újkritikusok a 'szoros olvasást'. Olyan eljárás ez, amely az irodalmi müvet mint bonyolultan kidolgozott [intricately crafted] tárgyat vizsgálja, amelynek szavai 'szerves' struktúrává állnak össze, és e struktúrát pontos konnotációk és tökéletesen ellenpontozott irónia támasztják alá." (Hammond, 2017. 33.). Ebböl a definícióból egyrészt kiviláglik, hogy a szoros olvasás optimális tárgya nem a nagyregény, hanem az áttekinthető terjedelmü lírai költemény. Vagyis a szoros olvasásra való hivatkozás nem oldja meg a Háború és béke olvasásának problémáját. Másrészt a meghatározás beleillik Hammond értelmezésébe, mely szerint az Új Kritika és általában a modern irodalomtudomány irodalomfogalmát a médiaversengés ösztönözte. Hammond ebből Hayles-énél is optimistább következtetést von le: amennyiben a médiatörténet korábbi fordulópontjai az irodalom újradefiniálásához vezettek, sőt az irodalmi gondolkodás éppen a huszadik század eleji médiarobbanás nyomán érte el legnagyobb kiterjedését, akkor a digitális átalakulás sem vezet az irodalom halálához. Éppen ellenkezőleg: szerinte a mediális átalakulás éppen a kreatív újragondolás szükségét mutatja meg, az irodalom alkalmazkodókészségét teszi próbára (Hammond, 2017. 22.).

Némiképp más látószögből közelít a modernitás kérdéséhez J. Pressman a Digitális modernizmus címü könyvében. Hammond mellett ô is kiemeli a modern
A szoros olvasás és a digitális közegek összekapcsolása mégsem egészen véletlenszerú és rendre vissza is tér a téma újabb szakirodalmában. A. Hammond, az Irodalom a digitális korban címú monográfia szerzóje is rámutat az Új Kritikában kidolgozott módszer médiatörténeti jelentóségére. Szerinte a modern irodalomtudomány

kialakulása nem elválasztható a távközlés modern fejlódésétól, a szoros olvasás metodikáját pedig már éppen a felgyorsult modern társadalom és a megszaporodó médiumok miatti aggodalom hívta eló. „Az Ujj Kritikát arra a hitre alapozták, hogy az irodalmi nyelv eltér az irott nyelv egyéb formáitól [...], és éppen emiatt az irodalmi nyelv az irodalomtudomány voltaképpeni fókuszpontja. Ebból a célból szorgalmazták az újkritikusok a 'szoros olvasást'. Olyan eljárás ez, amely az irodalmi múvet mint bonyolultan kidolgozott [intricately crafted] tárgyat vizsgálja, amelynek szavai 'szerves' struktúrává állnak össze, és e struktúrát pontos konnotációk és tökéletesen ellenpontozott irónia támasztják alá."

(Hammond, 2017. 33.). 
irodalomtudomány és a modern médiatechnológia kötődéseit; mindkettejük számára kézhezálló hivatkozás, hogy a modern médiaelmélet prófétája, McLuhan „újkritikus” irodalmárként, I. A. Richards és F. R. Leavis tanítványaként kezdte a pályáját. Pressman a kortárs digitális médiakultúrába beágyazott kísérleti múveket elemez, és ezeket rendre a huszadik századi modernizmus alkotásaival vagy jelenségeivel veti össze. A modern irodalom kísérleti alkotásai már eleve olyan médiatörténeti konfigurációkba rendeződnek, amelyeket visszamenőleg könnyü a digitalizációhoz kapcsolható jelenségek előzményeinek tekinteni. William Poundstone 2005-ös digitális müve például Bob Brown 1931-ben publikált antológiájára utal vissza, amely jelentős modernista szerzők (Ezra Pound, Gertrude Stein, W. C. Williams) tachitoszkópra írott, vagyis mechanikus sebességgel prezentálandó műveit tartalmazta. Az antológia Pressman értelmezésében a modernizmusnak a „gépesített poétikával” való összefonódását illusztrálja, aminek legegyértelmübb jele Williams egy esszéjéből idézett megállapítás: „Egy költemény olyan kis (vagy nagy) gépezet, amely szavakból áll” (idézi Pressman, 2016. 75.). Hasonló módon érintkezik a képernyő multimodalitására, a szoftver beállított sebességére és kísérőzenére írt digitális vers (Young-hae Chang Heavy Industries: Dakota) Ezra Pound Cantókjával. A tudatfolyam-technika (a példa Joyce Ulyssese) pedig a narratív és az adatbázis-szerü feldolgozás ellentétének dekonstrukcióját hajtja végre, amiből a kortárs digitális irodalom is inspirációt merít (Talan Memmott: My Molly (Departed)).

Talán a legizgalmasabb összefüggést a digitalizáció és az irodalmi olvasás között a Kódolvasás címü fejezet mutatja be, amely a számítógépes kódot mint ,univerzális nyelvet" elképzelő kortárs elképzelések filozófiai és irodalmi előzményeit (Leibniz; Pound és a kínai ideogramma; Ogden, Richards és a Basic English) mutatja be. Egyfelől itt is arra figyelhetünk föl, hogy a nyelvi és testi közvetítést kiküszöbölő, közvetlen információátvitel techno-fantazmagóriája az irodalmi modernizmus ideológiáihoz is köthető. Ugyanakkor ez az összefüggés az irodalmi újítás önmegsemmisítő potenciálját is megmutatja: a nyelvi korlátokon túli nyelv és az irodalmi konvenciók nélküli irodalom vágyképének paradoxonával szembesít. Az egyik fö ellentmondás a digitális kommunikáció állítólagos egyetemessége és az angol nyelv (vagyis egy sajátos, történetileg és kulturálisan határolt nyelv) dominanciája közötti feszültségből fakad. Pressman (2016. 157.) itt olyan kortárs digitális müveket mutat be (Erik Loyer Chroma című regényét és a Young-hae Chang Heavy Industries Nipponját), amelyek kihívást intéznek az „univerzális nyelv ideológiájának” és „fontos kettős szerepet töltenek be kortárs kultúránkban: ellenállnak a kibertér hallucinációjának és rávilágítanak az irodalom fontosságára digitális korunkban”.

A szoros olvasás újradefiniálása fontos adalékot ad ahhoz, hogy miként képzelik el az itt idézett szerzők az irodalmi kultúra továbbélését a digitális közegben. Pressman a médiatudatosság és a digitális írástudás jelentésmezejéhez köti az átértelmezett fogalmat: szerinte a digitális korban a médiaeffektusok felismerésének és elemzésének képessége nélkülözhetetlen, így a „médiatárgyak és -alkotások szoros olvasásának képessége” továbbra is a központban marad. Szellemes példaként a Google terméknévhez tartozó grammatikai ambiguitás (egyszerre használjuk tulajdonnévi, köznévi és igei funkcióban) és a honlapnak a többértelmüséget megjelenítő fehér háttere közötti összefüggést említi. Ennek felismerése ahhoz segíti hozzá Pressman egyetemi hallgatóit, hogy a sokszor látogatott weblapra szövegként tekintsenek, és ezáltal lehetővé váljon annak kritikai olvasása, elemzése (Pressman, 2016. 19.). A szóhasználatból, valamint abból, hogy a szerző a kritikai gondolkodás képességének metonímiájaként továbbra is a szövegolvasást használja, igazolódik a fentebb idézett elképzelés arról, hogy a szövegre és az irodalomra továbbra is mint a médiumok és a közvetítettség reflexiójának kitüntetett helyére gondolhatunk. Hasonló gondolatmenetet mutat be Oláh Szabolcs tanulmánya, amely az irodalom- és a médiatudomány közötti köztes helyzetben dolgozó oktató didaktikai célkitüzéseit fogalmazza meg. Eszerint az irodalmi (retorikai) olvasás képes rámutatni 
a valóság és az érzékelésünk közötti különbségre (Oláh, 2018. 130.), amely az analóg fényképen jelöletlen, mozgóképen nehezen észlelhető, a digitális médiumokban pedig a felhasználó számára rejtett (kódolt). Az irodalmi szöveg nyomán keletkezett (képzeletbeli) médiaeffektus és a szintén az olvasó szeme elött lévő szöveg különbsége azonban feltárhatja az érzékelt és a materiális valóság közötti eltérést. A szoros (retorikai) olvasás pedagógiai funkciója tehát a médiatudatosság fokozásában érhető tetten.

Itt érdemes megjegyezni, hogy a szakmódszertani irodalomban a kritikára, reflexióra, tudatosságra eső hangsúly indokolt ellenállást is kivált. Az irodalomolvasás fent már szóbahozott kettősségét: az élvező és az értelmező, a belefeledkező és a kritikus olvasás együttállását könnyen eltorzítja az állandó reflexióra és kritikai elemzésre irányuló figyelem. A kétféle olvasásmód összefüggéseit $\mathrm{Ch}$. Vischer Bruns mutatta be a Miért az irodalom? címü kitünő munkájában, és nehezen cáfolható az a megfigyelése, hogy a kettő csak egymásra vonatkoztatva érthető meg. P. Ricoeur nyomán így fogalmaz: ,a kritikai olvasás fejleszti (develops) a belemerülő olvasást, a belemerülő olvasás pedig körülveszi (envelops) a kritikait, és értelmet ad neki” (Vischer Bruns, 2010. 78.). Ezért nem szabad elhanyagolni a belefeledkezés, belemerülés, képzeletbeli világalkotás képességét sem, amelyet a kritikai mozzanatra eső túlhangsúly veszélyeztet. Már az elméleti irodalomtudomány is gyakran szembesül azzal a problémával, hogy az analitikus-kritikai megközelítésmód iskolai túlsúlya - „,a rosszul hangszerelt értelmezési gyakorlat" (Culler, 2015. 170.) - azelőtt kiöli a gyerekekböl az irodalom szeretetét, hogy valóban képesek lennének értelmező olvasóvá válni. Az irodalomoktatás 2.0-verziójáról szólva S. Giusti (2015. 100.) a szüken értett analitikus szemléletet a müvészet és az irodalom kontextuális-társadalmi funkciójának összefüggésében tágítaná ki, és ehhez nem csak a közösségi média kollaboratív eszköztárát használná föl, hanem erősítené az irodalmi szöveg hangzó aspektusának, előadásának és közösségi megtapasztalásának lehetőségeit is.

Ennek fényében nem meglepő, hogy a digitális szakmódszertanban a kritikai olvasás szövegközpontú megközelítésmódjai is új közösségi, kontextuális és technológiai környezetbe ágyazódnak. A digitális oktatási gyakorlat összefüggésében értelmezi újra a szoros olvasást J. Mathews esettanulmánya, amely az irodalmi olvasás és a kortárs technológiahasználat között analógiákat is keres. A szoros olvasásra mint átvihető készségre tekint, amely a kritikai elemzés mellett a releváns kontextus bemutatását, a szakmai fogalmak használatát és a kutatást is magába foglalja (Mathews, 2017. 226.). Mathews egy népszerü szabadidős kutatótevékenység, a geocaching segítségével mutatja be a szoros olvasás módszertanát diákjainak. Ez a tevékenység a kincsvadászat egy formája, amelyben a vadászok GPS-technológia segítségével kerülnek az elrejtett kincs közelébe, de a helyszínen maguknak kell felfedezni az elrejtett tárgyat. Mathews arra kérte diákjait, hogy a játék után foglalják össze a sikeres kereséshez vezető módszertani lépéseket, majd alkalmazzák ezt a procedúrát a szövegolvasásra. A szoros olvasás itt is egy rövid szövegrész alapos és részletes vizsgálatát jelenti, amelyre előzetes tanulmányok után „közelítünk rá". Az analógiából persze az is következik, hogy a technológiai segítség (a GPS használata) inkább a tágabb kontextus navigálásához járul hozzá, a szöveg vizsgálata már inkább az élő helyszínen történő vizsgálódásnak felel meg.

A szoros olvasás ilyen áttételes értelmezésének lépései Mathews (2017. 230-231.) bemutatásában a következők (a példa a Beowulf egy passzusa Seamus Heaney modern fordításában):

1. „Figyelmesen vizsgáld meg a környezetedet!” Ez az annotációt, az ismeretlen szavaknak vagy tudnivalóknak való utánanézést jelenti.

2. „Találj valamit, ami kitünik vagy nem illik a környezetébe!” Itt szembetűnő, érdekes stilisztikai részletek megfigyeléséröl van szó.

3. „Írd le ennek a stilisztikai részletnek a hatását!” Itt egyes szövegrészek részletes parafrázisáról, a retorikai-stilisztikai eszközök megnevezéséről, hatásuk elemzéséről 
van szó. Mathews példájában az irónia kerül előtérbe: a hősköltemény egy részletében a pogány motívumok és azok keresztény értelmezése adják az iróniát.

4. „Nyisd fel a ládát!” Itt a szerző a precízen leírt motívumok bátor értelmezésére buzdít. A láda kinyitása azt jelenti, hogy nem állunk meg a stilisztikai eszközök leírásánál, hanem az azokból adódó poétikai vagy ideológiai következtetéseket is levonjuk, pl. azt, hogy miként viszonyul a nyelvhasználat a szöveg bevallott szemléletmódjához. (Az adott példában a kard elolvadásának és a szörnyet rejtő tóba történő visszacsöpögésének motívuma a szerző szerint a pogány és a keresztény hitvilág „összeolvadásának” lehetőségét sugallja, szemben az elbeszélő nyílt kijelentéseivel.)

Az ilyen szellemü tanításmódszertant nem könnyü összehangolni az alapvetően narratív, irodalomtörténeti tudásátadásra építő magyar tantervi hagyományokkal. A kutatócsoportunk által szervezett iskolai munkában ezért egyelőre elsősorban nem a digitális (born-digital) irodalomra, nem is a modernség médiakonfigurációira helyeztük a hangsúlyt, hanem arra kértük az együttmüködő tanárokat, hogy a létező tantervek által amúgy is kijelölt irodalmi szövegeket dolgozzák fel digitális eszközökkel. A hangsúly mindig a szövegfeldolgozásra esik, de igyekeztünk olyan módokat előtérbe állítani, amelyek a szövegolvasást kooperatív, társasági tevékenységekbe ágyazták. Így már a kísérlet első fázisában is szövegek közös digitális annotációját végezték a tanulók. A további fázisokban ráadásul a szövegek feldolgozásában az aktív-interaktív mozzanatra került a hangsúly: az olvasás eredményeképpen már nem elemző-értelmező szövegek, hanem kreatív szövegek, gondolattérképek és videók jöttek létre. Ezek látszólag elvezetnek az irodalomértelmezés szaktudományos kontextusától, amelyben az irodalmi mü feldolgozása is szöveges formában, értekezések keretében történik. A kutatást vezérlő kérdések között azonban továbbra is ott szerepel az irodalom és az irodalomértés mibenlétének problémája. Az itt következő bemutatásban ezért arra helyezzük a fö hangsúlyt, hogy a kísérleti eredmények szerint a digitális környezetben végzett iskolai tevékenységek miképpen járultak hozzá a feldolgozandó irodalmi müvek megértéséhez.

\section{A kutatás célja, hipotézisei}

A kutatás célja megvizsgálni, hogy a különböző digitális eszközök és alkalmazások hogyan integrálhatók egy befogadásközpontú és kompetenciafejlesztő irodalomtanulási folyamatba, ahol kiemelt szerepe van az irodalmi szöveg elmélyült értelmezése során létrehozott kreatív, elemző, multimediális tanulói produktumoknak (Füzfa, 2015. 92.; Pethőné, 2005. 82.; Smith, 2017. 393.). A kutatás egy iskolai kísérlet segítségével vizsgálja meg, hogy a digitális eszközökkel, alkalmazásokkal dolgozó magyartanárok milyen pedagógiai, módszertani és technikai kihívásokkal szembesülnek a tanulási-tanítási folyamatban, valamint összegyüjti, hogy milyen jó gyakorlatokat dolgoznak ki a különböző témakörök tanítására. A kutatásban kiemelt figyelmet kapnak a diákok visszajelzései a digitális eszközök és alkalmazások irodalomórai integrációjáról. A diákok az eszközök és alkalmazások tanulási folyamatban betöltött szerepéről, szövegértelmezési lehetőségekről és a kollaboratív munkavégzésről fogalmazták meg a véleményüket. Jelen tanulmány a felsorolt célok és szempontok közül elsősorban az irodalomórai digitális szövegolvasás és -feldolgozás módszertani elemeit, az irodalmi szövegértelmezés lehetőségeit mutatja be és értékeli mind a tanárok, mind a diákok szemszögéből.

A kutatás első hipotézise, hogy az iskolai kísérletben részt vevő pedagógusok a különböző digitális eszközöket és alkalmazásokat megfelelőnek találták különböző szövegfeldolgozási módszerek megvalósítására. Az eszközök és alkalmazások lehetőséget 
adtak az értő olvasást és a hatékony megértést támogató tanulóközpontú gyakorlatok megvalósítására.

A kutatás második hipotézise, hogy a diákok hasznosnak tartották a különböző digitális alkalmazások szövegértelmezési funkcióit. Az alkalmazások segítségével jobban elmerültek a szövegek értelmezésében, sokkal inkább élményként élték meg a szövegekkel való foglalkozást, mint a hagyományos, papíralapú szövegértelmezési feladatok esetében.

A kutatás harmadik hipotézise, hogy az iskolai kísérlet jelen tanulmányban vizsgált két szakasza közül - kreatív-produktív szakasz és multimediális szakasz - a pedagógusok és a diákok is a multimediális szakaszt értékelik sikeresebbnek a szövegértelmezés, -feldolgozás terén.

\section{A kutatás módszere, eszköze, kísérleti személyek}

A kutatás alapvető módszere az iskolai kísérlet, amelyet egy 2016/2017-as tanévben lezajlott pilot vizsgálat előzött meg. A pilot vizsgálatban kidolgoztuk az iskolai kísérlet mérőeszközeit, amelyeket a 2017/2018-ban három szakaszban zajló iskolai kísérlet során alkalmaztunk (Molnár és Gonda, 2018). Az iskolai kísérletben a részt vevő pedagógusok saját tanmenetükhöz és csoportjukhoz illeszkedő tematikus egységeket dolgoztak ki és valósítottak meg különböző szövegfeldolgozási fókuszokkal. A kísérlet középpontjában tehát elsősorban nem a digitális eszközök és alkalmazások álltak, hanem a pedagógusok az adott témakör irodalomtanítási és szövegértelmezési céljainak rendelték alá a különböző digitális lehetőségeket.

A kutatás első szakaszában, a pilot vizsgálathoz hasonlóan, klasszikus szövegfeldolgozási eljárásokat valósítottak meg az irodalomórán digitális eszközök segítségével. Itt elsősorban a szoros szövegolvasáson volt a hangsúly, ahol többségében líraszövegek kerültek elötérbe, amelyeket többféle szövegértelmezési szempontból is annotáltak a diákok (Pallo, 2017). Ez a szakasz még kevésbé kedvezett az önálló tanulói produktum létrehozásának, ezért az iskolai kísérlet ezen részének eredményeit ebben a tanulmányban nem ismertetjük.

Az iskolai kísérlet második szakaszában kreatív-produktív gyakorlatok segítségével dolgozták fel a diákok a különbözö irodalmi szövegeket. A kreatív-produktív szövegfeldolgozás fogalmát csak részben a Petőfi S. János és Horváth Zsuzsa által kidolgozott módszertani értelemben használjuk (Petőfi S. és Benkes, 1998a, 1998b). A módszer célja továbbra is az előzetes tudás aktiválása, a bevonódás, az egyéni olvasat megfogalmazása, a közös tudásépítés, reflektálás segítése, azonban a kaleidoszkopikus és a kreatív-produktív típus mellett megjelenik a hipertextuális (Petőfi S. és Benkes, 1998b. 55.), amely a szövegek újraértelmezését és -alkotását digitális térben teszi lehetővé (Petőfi S. és Benkes, 1998b). Az iskolai kísérlet ezen szakaszában az átalakító, létrehozó, kiválasztó müveletek mellett megjelennek a szintetizáló gyakorlatokat, amelyek a szöveg jelentésének és értelmezésének hálózatos megjelenítését támogatják. A kísérlet ezen szakaszában a pedagógusok kétféle digitális eszközt alkalmaztak: a szövegek hálózatainak feltárásában egy gondolattérkép-készítő alkalmazást (Relatime Board), a szövegek újraalkotásához, valamint új szövegek alkotásához pedig egy kollaboratív digitális jegyzetfüzetet (Etherpad.net).

Az iskolai kísérlet harmadik szakaszában multimédiás szövegfeldolgozási gyakorlatokat végeztek a diákok, az adott irodalmi szövegekből kiindulva saját képi, illetve filmes adaptációkat hoztak létre. A kísérlet ezen szakaszának újdonsága, hogy a multimédiás eszközök nem a tanár szemléltetőeszközeként jelennek meg (Füzfa, 2015. 92.; Pethőné, 2005. 139-143.), hanem az irodalmi szöveg értelmezésének egy lehetséges 
módszereként (Smith, 2017. 379-380.). A kísérlet ezen szakaszában a diákok szintén kétféle alkalmazással dolgozhattak: képszerkesztő programmal (Canva, Photoshop), amely segítségével plakátot készítettek az adott irodalmi münek egy szövegelemzési kérdéséről; vagy videoszerkesztő porgrammal (Stop Motion Studio, Windows Movie Maker), amellyel különböző elemzési szempontú etüdöket készítettek.

Az iskolai kísérletben a 2017/2018-as tanévben összesen öt intézmény (budapesti középiskolák) hat pedagógusa vett részt. A hat pedagógus öt különböző digitális alkalmazást tesztelt a tanév során, összesen 18 tematikus tervet készítettek, amelyek elérhetők kutatócsoportunk honlapján (1). A pedagógusok egy reflektív interjú keretében számoltak be az iskolai kísérlet egyes szakaszainak tapasztalatairól, így összesen 36 interjút rögzítettünk. A magyartanárok egy-egy osztályukban, illetve csoportjukban valósították meg az iskolai kísérletet, ennek megfelelöen összesen 292 diák vett részt a projektben, akik minden szakaszt követően egy-egy véleménykérő kérdőívet töltöttek ki irodalomórai élményeikről.

\section{Eredmények}

\section{A kreativ-produktív szakasz}

Az iskolai kísérlet kreatív-produktív szakaszában a pedagógusok elsődleges feladata az volt, hogy olyan szövegelemző gyakorlatokat dolgozzanak ki a megadott eszközök segítségével, amelyek az eredeti szöveg átalakításával, újraírásával, új szövegek létrehozásával valósítják meg az értelmezési folyamatot. Az egyik eszköz egy gondolattérkép-készítő program volt (Realtime Board), amelyet azért választottunk, mert grafikus szervezö lévén mindenképpen megtöri egy szöveg linearitását és az egyes szövegelemek újrastrukturálását igényli az olvasótól. A másik eszköz egy kollaboratív digitális jegyzetfüzet (Etherpad.net) volt, amely hosszabb szövegek alkotására, átrendezésére, átírására különösen alkalmas, hiszen a jegyzetfüzetbe belépő felhasználók ugyanazt a szöveget manipulálják. Mindkét eszközt alkalmazták a pedagógusok különböző münemű szövegek értelmezésére.

\section{Gondolattérkép}

A pedagógusokkal felvett reflektív interjúk alapján kijelenthetjük, hogy módszertani szempontból kevésbé tartották sokoldalúnak a Realtime Board nevü eszközt. Többen megjegyezték, hogy a beépített sablonok inkább az anyaggyüjtést és rendszerezést, egy-egy szöveg megalkotásának előkészítését segítették, és kevésbé voltak alkalmasak mélyebb szövegértelmezésre. Inkább csak epikai müvek esetében készítettek a pedagógusok a Realtime Board segítségével a szöveget újrastrukturáló gyakorlatokat, ilyen volt például az Üvöltő szelek regényelemzésekor a betegségek és a narráció kapcsolatának szerkezeti ábrázolása, amely jól illeszkedett a program egyik sablonjába, ahogyan az az 1. ábrán is látható. 


\section{Betegségek}

Panna, Sz. Dani, Vera
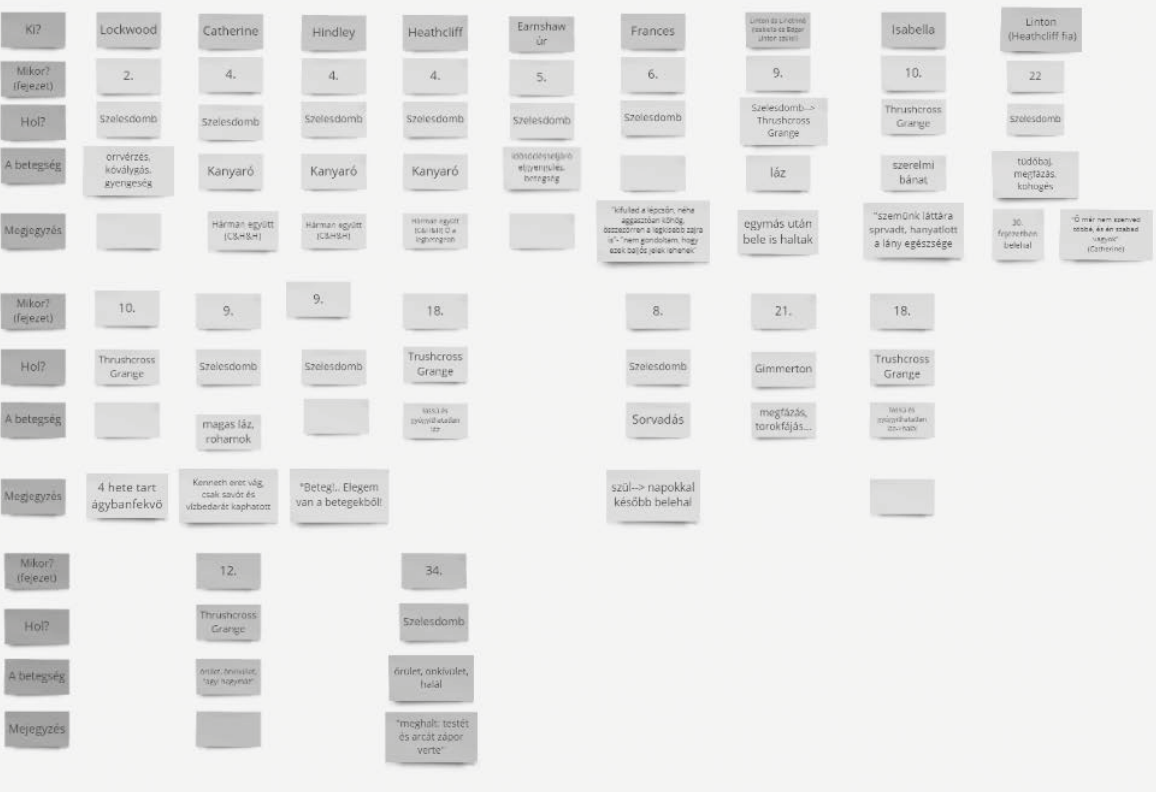

1. ábra. Az Üvöltő szelek elemzése Realtime Boardon (2)

A szövegelemzés szempontjából a tanárok a Realtime Board előnyeként nevezték meg a közös tudásépítés lehetőségét, hiszen a diákok egyszerre többen is szerkeszthetik a felületet, így kollaboratív módon gondolkodhatnak egy adott müről vagy témáról. Ezt a folyamatot támogatják az eszköz beépített sablonjai is, amelyek alkalmasak az egyes gondolatmenetek, elemzési feladatok, narratív struktúrák szerkezeti leképezésére. Az eszköz alkalmasnak bizonyult rövid szövegidézetek megjelenítésére, értelmezésére, vélemények megfogalmazására, amely nagyban segítette az önálló olvasat kialakítását. Szintén előnye az eszköznek, hogy támogatja a képek, mozgóképek beillesztését, amely motiválóbbá és szemléletesebbé teszi a tananyagot. Hátrányként élték meg a pedagógusok, hogy az eszköz kevésbé támogatja a hosszabb szövegek alkotását, így elsősorban címkézésre, feliratok készítésére alkalmas. Ezért többen is úgy vélték, hogy szoros olvasásban, lírai szövegek elemzésében kevésbé hatékony. Mindannyian megfogalmaztak technikai nehézségeket is az eszközzel kapcsolatban, leginkább a körülményes használatot emelték ki.

A Realtime Board különböző funkcióit kihasználva a kísérletben részt vevő pedagógusok a következő szövegfeldolgozási müveleteket, illetve gyakorlatokat végezték el diákjaikkal:

- anyaggyüjtés,

- a gyüjtött elemek rendezése,

- elemzési feladat megoldása (pl. jellemtérkép készitése, narrációs struktúra ábrázolása),

- szövegrészek sorba rendezése,

- szövegalkotás. 
A diákok 1-től 5-ig tartó skálán értékelték, hogy melyik funkció milyen mértékben segítette saját szövegértelmezési folyamatukat $(1=$ egyáltalán nem, $5=$ teljes mértékben $)$. Ahogyan a 2. ábra is szemlélteti, a különböző funkciók közepes mértékben járultak hozzá a diákok szövegelemzéséhez, leghatékonyabb funkciónak a tanulók a gyüjtött elemek rendezését ítélték. Ez az érték összhangban van a pedagógusok véleményével, akik szerint szintén inkább anyaggyüjtésre és rendezésre lehet ezt az eszközt funkcionálisan alkalmazni az irodalomórán.

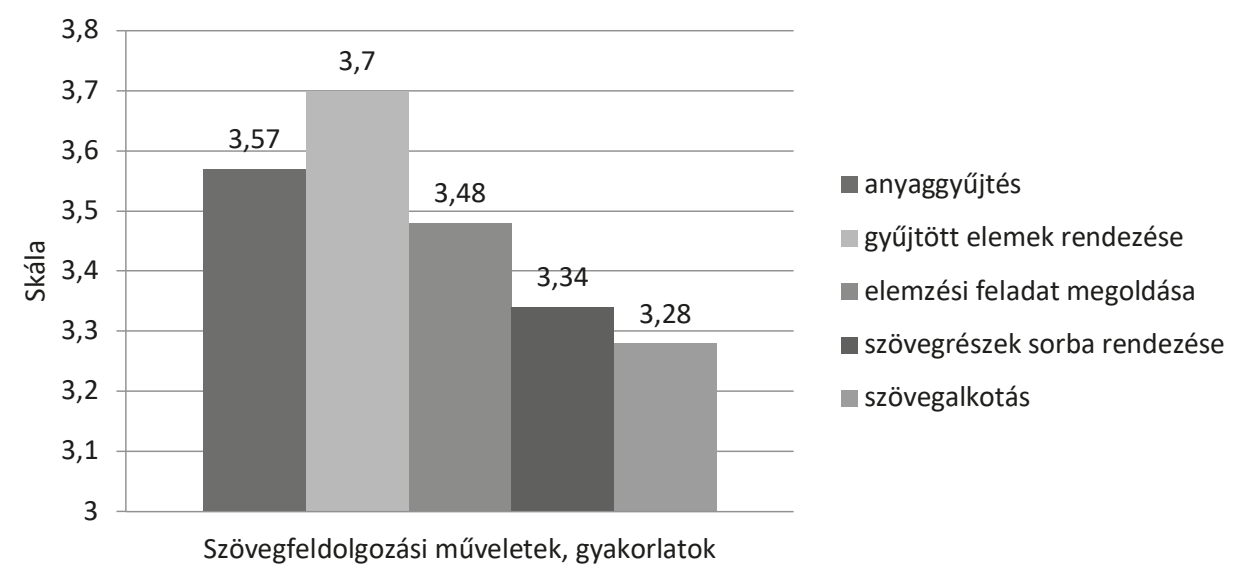

2. ábra. A Realtime Board szövegelemzési funkciónak az értékelése ( $N=90$ fö)

Bár a diákok alapvetően közepesre értékelték az eszköz hasznosságát, számos olyan szöveges vélemény, visszajelzés született, amely a szövegelemzés elmélyültségére, saját olvasat kialakítására utal: „Segít a cselekmény ismertetésében és ábrázolásában, megkönnyíti a kapcsolati háló valamint az összefüggések ismertetését.”; „Lehetőséget adott a gondolatok rendszerezésére, új perspektívába helyezésre.”

\section{Digitális jegyzetfüzet}

A kreatív-produktív szakasz másik digitális eszköze az Etherpad volt, amely szövegelemzési funkcióiról szintén összhangban van a tanárok és a diákok véleménye. Mivel ez a kollaboratív digitális jegyzetkészítő program egy alapvetően könnyen kezelhető, játékos, színes felület, ezért a pedagógusok a tervezés során attól tartottak, hogy a diákok figyelme majd elkalandozik, és kevésbé fogják tudni az eszközt komolyan venni. Ennek ellenére a kollaboratív munka, a szövegalkotási feladat mellett folyamatosan müködö csetablak, a színek, a szöveg manipulálhatósága sokkal inkább motiválta a diákokat a feladat elvégzésére. Az egyik pedagógus az Íliász tanítása kapcsán alkalmazta az eszközt, a diákok feladatmegoldása a 3. ábrán látható. A tanárnő így nyilatkozott a feladat elvégzését követően: „A két-három mondatnál hosszabb szövegek alkotásához használtam az eszközt, tökéletesen alkalmas volt a szerepjátékok révén, a kreatív írás segítségével alapvető emberi magatartások felismerésére és azonosítására, az elbeszélői nézőpontok megismerésére és gyakorlására." 


\section{AZ ILIÁSZ SZEREPLŌI}

\section{Mutatkozz be néhány mondattal a szereped szerint!}

\section{Én vagyok Akhilleusz}

Édesanyám Thetisz Istennō, édesapám Péleusz halandó ember, dédnagyapám a nagy Zeusz Isten. Édesanyám életemet féltve a Sztüx vizébe mártott, hogy örökké sebezhetetlen legyek. Azonban lábam azon része, ahol a bokámnál tartott, nem érhetett hozzá a halhatatlanná tévō folyadékhoz, ez okozta késôbbi halálomat. Nevelőm a csodálatos Kheirón kentaúr, akitōl megtanultam harcolni, vadászni, lovagolni, gyógyitani és lanton játszani. A Trójai háború legkiválóbb harcosa voltam. Barátom, Patroklosz halála szörnyũ haragra gerjesztett, leszámoltam gyilkosával, Trója királyának fiával, Hektórral. Halálomat a híres Szkaiai kapunál Parisz (Apollón segítségével) okozta, nyilvesszôvel eltalálta egyetlen sebezhetô pontomat, a sarkamat. (T.Alex A.)

Péleusz vagyok. Aiakosz és Endeisz fia. Zeusz engem jelōlt ki Thétisz férje gyanánt.Feleségem Thétisz, és az én lakodalmamon tört ki a viszály, ami a trójai háborúhoz vezetett. Erisz beguritott egy aranyaimát "A legszebbnek" felirattal. Héra, Pallasz Athéné és Aphrodité meg akarták szerezni maguknak az aimát. Aphrodité tett Párisznak egy igéretet: nekiadta Helenét. Héra és Pallasz Athéné roppant haragja gerjedt. Elhatározták, hogy Trójának pusztulnia kell. Sz.R.

\section{Khrüszéisz: Khrüszész pap lánya vagyok, amikor a görögök lerohanták Müsziát, elvittek magukkal rabszolgának. Agamemnón király szolgái közé kerültem. Apám eljött a táborba és megpróbált kiváltani, de a görögök kinevették és elüildözték. Megbánták, mert dögvész sújtotta táborukat. Végí visszamehettern apámhoz, Odüsszeusz saját maga vitt vissza neki. (P.A.)}

Polüdeukész vagyok, Tündareósz és Léda fa, de az igazi apám Zeusz, a bátyám pedig Kasztor. Mi ketten rész vettünk egy sor veszélyes harcban és kihivásban, mint az Argonauták útja vagy a Kalüdóni vadkanvadászat. Megmentettük a húgunkat Helenét az amazonok markából. De egy nagyobb harcot követōen a bátyám, Kasztor meghalt, és le akartam mondani a halhatatlanságomról. Ezt hallva Zeusz úgy dōntōtt, hogy én és a bátyám együtt maradhatunk, de csak akkor, ha megosztozunk a halhatatlanságon. Azaz, az egyik nap az égben, a másik nap pedig az alvilágban élūnk. R.F.

Pallasz Athéné: A város és a polgárok védelmezōje vagyok. Célom az igazságos háború, de a mūvészetet és a kézmūvességet is keơvelem. Apám, Zeusz fejéböl pattantam ki, teljes felszereltségben, magasra tartott dárdával, akár felhôból a villám. Apámmal mindenben egyetértek, nagyon jól kjöwūnk. Kedvenc álatom a bagoly. Egyszer versenyeztem Poszeidónnal Athenae városáért, természetesen én gyóztem. Egy jó cselekedetet kellett végrehajtani az embereknek, egyfajta ajándékot. A tengerek ura háromágú szigonyát a várhegynek sziklájába döfte, mire víz fakadott belóle. Én viszont közvetlenül mellette kikeltettem az elsô olajfát. Ez nemcsak az embereknek, de az isteneknek is nagyon tetszett, úgyhogy most már én uralkodok azon a területen. Sz.S.

\section{3. ábra. Antik hösök és istenek bemutatkozása az Etherpad.neten}

A pedagógusok a következö előnyöket fogalmazták meg az Etherpad.nettel kapcsolatban: - játékos, kreativitásra ösztönzö felület,

- alkalmas hosszabb szövegen is végrehajtható kreatív-produktív gyakorlatok megvalósítására (átírás, újraírás, alkotás),

- támogatja a közös tudásépítést, több résztvevő egyidejü munkája is lehetséges.

A diákok is hasonló elönyöket fogalmaztak meg a saját szavaikkal: „Egyidejű munka csoportban, többféle gondolat egy helyen, lendít a gondolkozáson, a chatablakban is elemző kérdéseket lehet feltenni és megválaszolni, amit utána szintén be lehet mutatni, mint fontos munkafolyamatot.”; „Tetszett, hogy a saját véleményemet írhattam, szintén egy olyan helyre, ahol online volt minden, tehát láttam, amit mások írnak abban a pillanatban."

Az Etherpad.net szövegelemzési funkciói jobb értékelést kaptak a diákoktól, mint a gondolattérkép-készítő programé. Az átlagértékek ebben az esetben szinte már a ,jó" kategóriát érintik. Az eszköz sokoldalúságát mutatja, hogy több funkció is 3,7 feletti átlagértéket kapott a diákoktól, ahogyan azt a 4. ábra is szemlélteti. Ez azt jelenti, hogy a felületet a diákok kimondottan hatékonyan tudták alkalmazni olyan szövegelemzési gyakorlatokban, mint a vélemény megfogalmazása, szöveg átírása és alkotása, valamint elemző feladatok megoldása. 


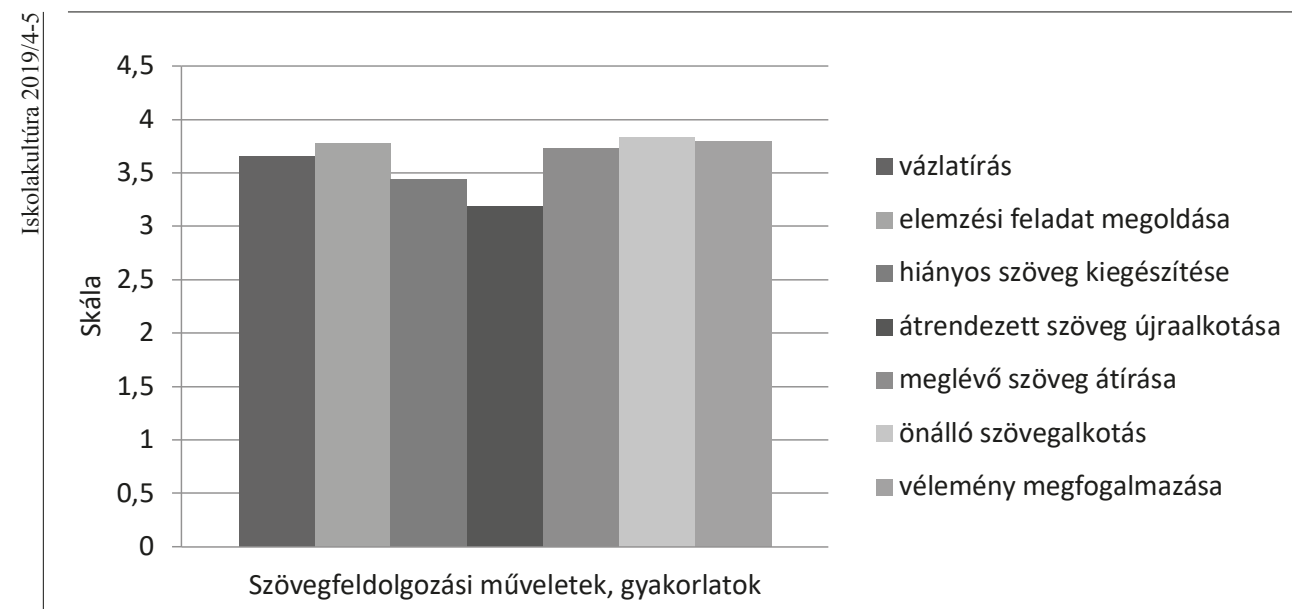

4. ábra. Az Etherpad.net szövegelemzési funkcióinak az értékelése ( $N=90$ fö)

Természetesen ezzel az eszközzel kapcsolatban is említettek hátrányokat mind a tanárok, mind pedig a diákok. A tanárok elsősorban a felületen zajló munka értékelésének a nehézségét emelték ki, hiszen a végső szövegváltozat esetében már nehéz megállapítani, hogy ki mennyit dolgozott az adott szövegen. Továbbá néhányan megemlítették, hogy a csetablak és a különböző színek valóban elvonták egy-két diák figyelmét a komoly munkától a feladatmegoldás elején, de miután hozzászoktak a felülethez, már ők is motiváltan dolgoztak. A diákok ezzel szemben inkább csak technikai problémákat hoztak szóba.

\section{Multimédiás szövegfeldolgozás}

A multimédiás szövegfeldolgozás szakaszában is két digitális eszközzel dolgozhattak a tanárok és a diákok. Lehetőséget kaptak képszerkesztő programok használatára, amelyek a szöveget egy másik médium segítségével, alapvetően képi és nem verbális elemekkel jelenítik meg és értelmezik. A plakátkészítés során a magyartanárok arra sarkallták diákjaikat, hogy saját fényképekkel, képekkel valósítsák meg elképzeléseiket, segítve ezzel nemcsak a bevonódást, hanem az egyéni olvasat létrejöttét is. A két leggyakrabban használt eszköz a Canva és a Photoshop volt.

A multimédiás szövegfeldolgozás szakaszában videoszerkesztő programokat is alkalmaztak az iskolai kísérlet résztvevői. A kísérletben részt vevő pedagógusok célja az volt, hogy a diákok filmes eszközökkel legyenek képesek megjeleníteni gondolataikat egy-egy szöveggel kapcsolatban. Kimondottan elzárkóztak egy-egy történet újrameséléstől, és elsősorban a szövegek hangulatának, képi világának, elbeszélési technikáinak értelmezésére és filmes megjelenítésére adtak feladatot a diákoknak. A leggyakrabban alkalmazott videoszerkesztő programok a Windows Movie Maker és a Stop Motion Studio voltak.

Mindkét eszközben közös, hogy korábban is megjelentek már az irodalomórákon, de elsősorban a szemléltetés vagy a szövegértelmezés eszközeként. Egy-egy irodalmi szöveg kép segítségével történő elemzése vagy egy-egy képzőmüvészeti alkotás szövegben való megjelenése már korábban is hozzájárult egy-egy szöveg jelentésrétegeinek a feltárásához (Czibula, 2015. 176-178.). A mozgókép irodalomórai szemléltetésként való megjelenése, illetve egy-egy szöveg/szövegrészlet filmmel való helyettesítése is jellemző az irodalomórai gyakorlatban. Az ilyen filmrészletek alkalmasak arra, hogy rávilágítsanak egy-egy irodalmi mü központi elemeire, hozzájárulva ezzel a 
lényegi pontok kiemeléséhez az elemzés során (Füzfa, 2015. 92.). Ezzel szemben az iskolai kísérlet résztvevői mind a plakátokat, mind az elkészült kisfilmeket önállóan alkották, a létrejött tanulói produktumok messze túlhaladják a szemléltetés célját, a szöveg más médiumba való áthelyezése mélyebb értelmezési lehetőséget nyújtott a diákok számára, mint a hagyományos elemzési módszerek.

\section{Képszerkesztő programok}

A képszerkesztő programok alkalmazásával a pedagógusok egyik legföbb célja a kreativitás ösztönzése volt. Sokan beszámoltak róla, hogy a diákok motiváltak voltak feladatvégzés közben, és sokan elmélyültek az alkotásban. A diákok is hasonlóan vélekednek a képszerkesztő program használatáról: „Minden apró részletre figyelni kell, amihez alaposabban kell elolvasni a szövegrészletet, ezáltal jobban meg is lehet érteni azt."

A különböző témakörökben a plakátkészítéssel kapcsolatban a következő feladatrészekre bontották a munkafolyamatot a pedagógusok:

- a téma megjelölése,

- a kép/plakát szöveges tartalmának megírása,

- saját fotó készítése és alkalmazása,

- anyaggyüjtés: képek, ábrák keresése az interneten,

- a gyüjtött elemek rendezése.

Annak ellenére, hogy a tanárok elsősorban saját fényképekre, rajzokra számítottak, a munkafolyamat legsikeresebb részének az internetes kép- és ábrakeresés bizonyult, ami a diákok szerint nagymértékben segítette a szövegértelmezést $(4,03)$. Szintén kimondottan hatékonynak értékelték a diákok a gyüjtött elemek elrendezését, a plakát megalkotását $(3,83)$. A munkafolyamat egyes lépéseinek szövegértelmezési hatékonyságát a 3. ábra szemlélteti. Az eredményekhez hozzájárul, hogy a diákok 21,4\%-a teljes mértékben, 42,9\% inkább egyetért azzal az állítással, hogy a szövegek, szövegrészletek képen való ábrázolása a szöveg, szövegrészlet aprólékos ismeretét jelenti.
A multimédiás szövegfeldolgozás szakaszában is két digitális eszközzel dolgozhattak a tanárok és a diákok. Lehetóséget kaptak képszerkesztó programok használa-

tára, amelyek a szöveget egy másik médium segitségével, alapvetôen képi és nem verbális elemekkel jelenítik meg és értelme-

zik. A plakátkészités során a magyartanárok arra sarkallták diákjaikat, hogy saját fényképek-

kel, képekkel valósítsák meg elképzeléseiket, segítve ezzel nemcsak a bevonódást, hanem az egyéni olvasat létrejöttét is. A két leggyakrabban használt eszköz a

Canva és a Photoshop volt.

A multimédiás szövegfeldolgozás szakaszában videoszerkesztó programokat is alkalmaztak az iskolai kisérlet résztvevooi. A kisérletben részt vevó pedagógusok célja az volt, hogy a diákok filmes eszközökkel legyenek képesek megjeleniteni gondolataikat egy-egy szöveggel kapcsolatban. Kimondottan elzárkóztak egyegy történet újrameséléstól, és elsósorban a szövegek hangulatának, képi világának, elbeszélési technikáinak értelmezésére és filmes megjelenitésére adtak. feladatot a diákoknak. A leggyakrabban alkalmazott videoszerkesztó programok a

Windows Movie Maker és a Stop Motion Studio voltak. 


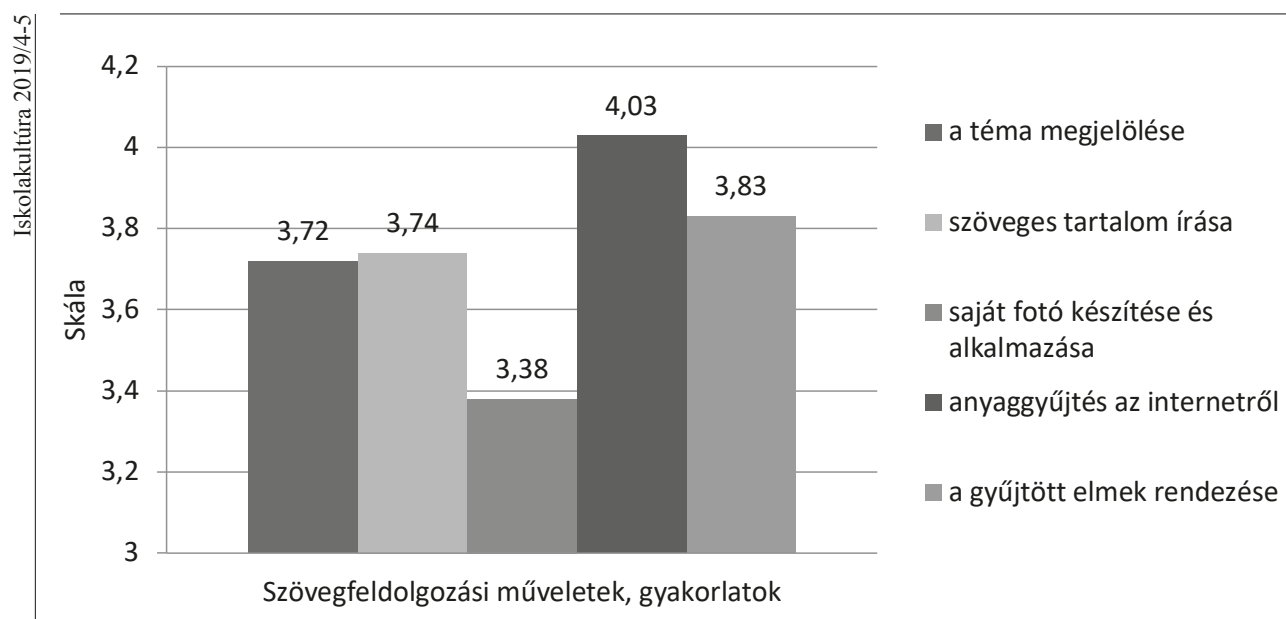

3. ábra. A képszerkesztö program szövegelemzö alkalmazásának értékelése ( $N=112$ fö)

Gyakran a statikus poszterek mellett interaktív plakátok is készültek, amelyek akár mozgóképek megjelenítésére is alkalmasak. A Hamlethez készült plakátokból a 4. ábrán láthatunk egy gyüjteményt.

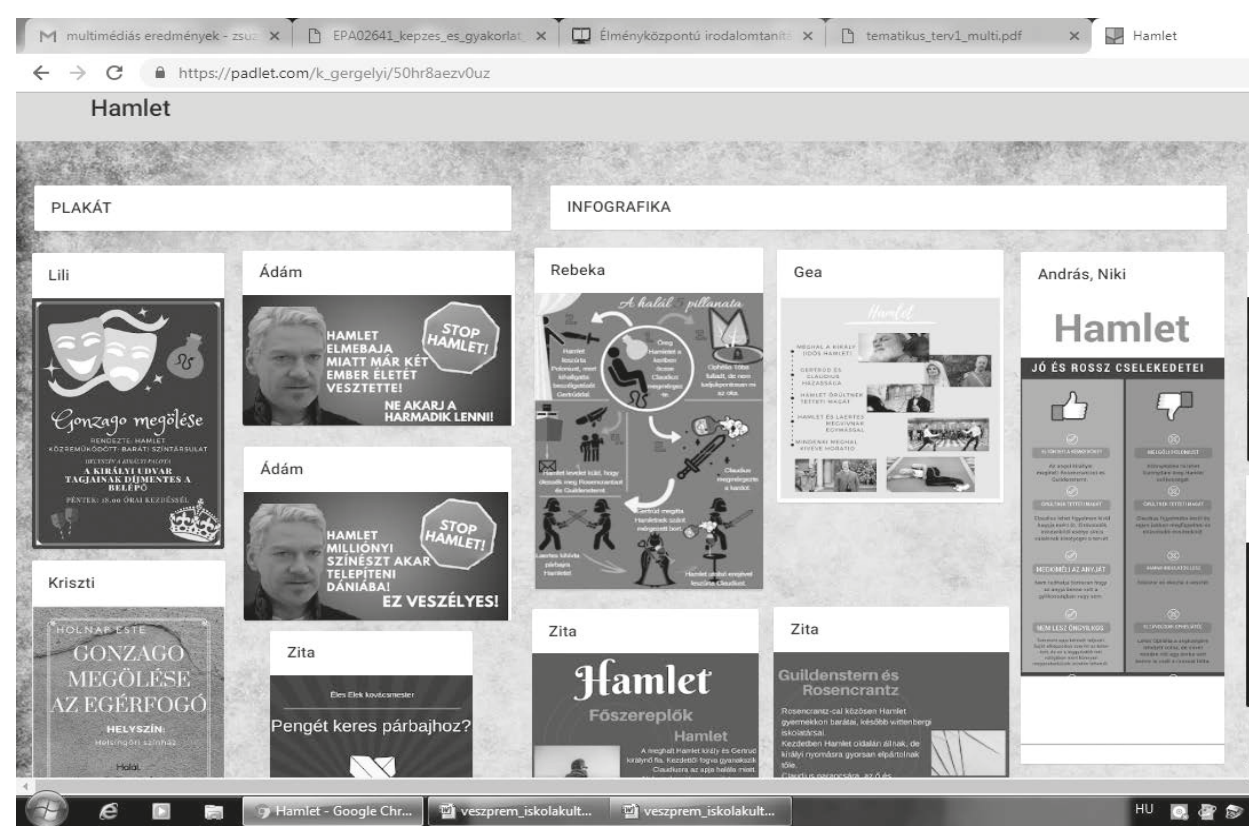

4. ábra. A Hamlet feldolgozása plakátok segitségével

\section{Videoszerkesztő programok}

Mind a tanárok, mind a diákok részéről az iskolai kísérlet leginkább motiváló szakasza a filmek készítése volt. Az előzetes várakozások beigazolódtak, minden tanár irodalom-módszertani, szövegelemzési szempontból sikeresnek tartotta a projektet. Többen 
megemlítették azonban, hogy filmes megvalósításban többet vártak a diákoktól, de ök is úgy vélték, hogy a szövegfeldolgozás minden videó esetében megtörtént. Az egyik pedagógus így nyilatkozott az osztályában készült videókról: „Az elkészült videók javarészével tanítani lehetne a választott verseket, hangulatokra, összetett képekre koncentrálnak, ritkábban csak tematikusan kapcsolódnak, de minden esetben eljutnak az önálló értelmezésig..."

A multimédiás szövegfeldolgozás legföbb előnyeként jelölték meg a pedagógusok, hogy a szövegek megismerése és újraalkotása segítette különböző írói eljárások megfigyelését és tudatosítását, valamint a szövegek stilisztikai eszközeinek képi megjelenítésének kidolgozása is nagyban hozzájárult egy-egy szöveg jelentésrétegeinek felfejtéséhez. További előnyként említették, hogy a diákok megismerkedhettek filmes fogalmakkal, fejlesztették a szövegalkotási kompetenciájukat a forgatókönyv elkészítésével, és saját gondolataikat közvetíthették a képek által. Nem elhanyagolható szempont, hogy a legtöbb csoport élvezte a közös munkát, és büszkék voltak az elkészült produktumokra.

Mind a diákok, mind a tanárok leginkább a munkafolyamattal kapcsolatban fogalmaztak meg nehézségeket, mindenkitől sok időt, egyeztetést kívánt a feladat, amit mindenképpen iskolaidőn kívül kellett megvalósítani. Sokan a diákok közül technikai kihívásokkal is szembesültek, könnyebben ment azokban a csoportokban a munka, ahol volt olyan diák, aki már dolgozott valamilyen vágóprogrammal.

A diákok szerint a szövegértelmezést leginkább a látvány megtervezése $(3,86)$, majd pedig a múfaj kiválasztása segítette $(3,83)$, de minden videokészítéssel kapcsolatos feladat 3,7 feletti értéket kapott a diákoktól az 5-ös skálán, ahogyan azt a 5. ábra is szemlélteti. A diákok 22,3\%-a teljes mértékben, 48,2\%-a inkább egyetért azzal az állítással, hogy a szövegek, szövegrészletek videós ábrázolása a szöveg, szövegrészlet aprólékos ismeretét igényli. A diákok többsége a szövegértelmezés hatékonysága mellett felhívta a figyelmet a kollaboratív munka előnyeire és a kreatív megoldások lehetőségeire az elemzési folyamatban: „A videó készítése közben újra átgondoltuk a történetet, hogy kitaláljuk, mik azok a fontos részek, amiket bele kell tenni a videóba, illetve, hogy hogyan tudjuk visszaadni a novella hangulatát filmes eszközökkel, narráció nélkül.”; „Izgalmas videókat csinálni, mert rengeteg ötletet lehet bennük kivitelezni. Más szemmel nézzük utána a filmeket. Élénkebben marad meg a szöveg."
A multimédiás szövegfeldolgozás legfóbb elönyeként jelölték meg a pedagógusok, hogy a szövegek megismerése és újraalkotása segitette különbözó irói eljárások megfigyelését és tudatositását, valamint a szövegek stilisztikai eszközeinek képi nagyban hozzájárult egy-egy szöveg jelentésrétegeinek felfejtéséhez. További elónyként emlitették, hogy a diákok megismerkedhettek filmes fogalmakkal, fejlesztették a szövegalkotási kompetenciájukat a forgatókönyv elkészitésével, és saját képek által. Nem elhanyagolható szempont, hogy a legtöbb csoport élvezte a közös munkát, és büszkék voltak az elkészült produktumokra. gondolataikat közvetithették a 




5. ábra. A videokészités szövegelemzö alkalmazásának értékelése ( $N=112$ fö)

\section{Összegzés}

A kutatás hipotézisei közül az első kettő egyértelműen, a harmadik pedig jórészt igazolódott.

1. A kísérletben részt vevő tanárok megfelelőnek találták a felhasznált eszközöket szakmódszertani céljaik megvalósítására. Ezt annyiban nem tekinthetjük meglepőnek, hogy egy részük már gyakorlott a digitális eszközök irodalomórai használatában, sőt egyesek a digitális pedagógia hazai úttörői között tarthatók számon. De a többiek is módszertanilag kiemelkedően tudatos pedagógusok, akik a kutatás felépítésében, az eszközök kiválasztásában is aktívan közreműködtek, és önállóan építették be a digitális eszközöket tanmeneteikbe. A kutatás következő szakaszában remélhetőleg tágabb körből, még változatosabb háttérrel rendelkező tanároktól kaphatunk visszajelzéseket.

2. A diákok is megfelelőnek találták a használt eszközök szövegértelmezési funkcióit, sőt kiemelték, hogy a kreatív-produktív és a multimédiás feldolgozás szükségessé tette és segítette az irodalmi szövegekben való elmélyülést. Ez a kutatás eddigi legpozitívabb eredményének tekinthető. A tanároktól és a diákoktól is olyan viszszajelzések érkeztek, amelyek a szövegek poétikai szempontú feldolgozására is vonatkoznak. A médiaközi váltás során a diákok kénytelenek voltak elgondolkodni az irodalmi nyelvhasználat sajátosságairól, a müvek hangulatáról és poétikai megoldásairól. A kutatás további feladatai közé tartozik a digitális közegben történő feldolgozás során az irodalmi szövegekre irányuló figyelem további vizsgálata a tanulmány bevezetőjében vázolt olvasási tipológia alapján.

3. Feltételeztük, hogy a pedagógusok és a tanulók is a multimediális feldolgozást fogják a legsikeresebbnek ítélni. Ez érdekes módon az értelmezés vonatkozásában igazolódott: itt kaptuk a legegyértelmübben elismerő visszajelzéseket a szövegfeldolgozás hatékonyságára vonatkozóan. Ugyanakkor sok válaszadó kiemelte ezzel a feladattal kapcsolatban a technikai nehézségeket, a tanárok pedig - a felismert szövegértelmezési hatékonyság ellenére - nem mindig voltak elégedettek az elkészült munkák színvonalával.

A kísérlet nyomán kapott visszajelzések azt jelzik, hogy a tanárok és a diákok alapvetően elégedettek voltak a digitális eszközök irodalomórai, szövegfeldolgozási célú 
felhasználásával. A kísérlet eddigi eredményei azt sejtetik, hogy a kreatív és interaktív digitális módszerek nem eltávolítják a diákokat az irodalmi szövegtől, hanem éppen elmélyíthetik és segíthetik az irodalom megértését.

\section{Irodalom}

Bengi László (2018). „Digitális”: közeg, olvasás vagy szemléletmód? In L. Varga Péter, Molnár Gábor Tamás \& Palkó Gábor (szerk.), Digitális (szöveg) kultúrák a bölcsészképzésben. Budapest: ELTE BTK. 34-55.

Carr, N. (2008). Is Google Making Us Stupid? What the Internet is Doing to Our Brains. The Atlantic, július-augusztus. Online: https://www.theatlantic.com/ magazine/archive/2008/07/is-google-making-us-stupid/306868/. Utolsó letöltés: 2019. 01. 11. DOI: 10.1111/j.1744-7984.2008.00172.x

Culler, J. (2015). Theory of the Lyric. Cambridge, Mass.: Harvard University Press. DOI: $10.4159 / 9780674425781$

Czibula Katalin (2015). Intermediális lehetőségek az irodalomtanításban. Arany János Zách Klára címü balladájának kulturális kontextusa. In Antalné Szabó Ágnes, Laczkó Krisztina \& Raátz Judit (szerk.), Bölcsészet- és Müvészetpedagógiai Kiadványok 2. Szakpedagógiai körkép I. Anyanyelv-és irodalompedagógiai tanulmányok. Budapest: ELTE. 176-196.

Dörr, V. C. \& Goebel, R. J. (2018). Einleitung. In uök (szerk.), Literatur in der Medienkonkurrenz Medientranspositionen $1800-1900-2000$. Bielefeld: Aisthesis.

Füzfa Balázs (2016). Élményközpontú irodalomtanítás a harmadik évezredben. In: uö (szerk.), IROM-könyvek 3. http://mek.oszk.hu/16400/16457/16457.pdf Utolsó letöltés: 2017. 05. 22

Giusti, S. (2015). Didattica della letteratura 2.0. Roma: Carocci.

Hammond, A. (2017). Literature in the Digital Age. An Introduction. Cambridge: Cambridge University Press.
Hayles, N. K. (2010). How We Read. Close, Hyper, and Machine. ADE Bullettin, 150. 62-79 DOI: 10.1632/ade. 150.62

Mathews, J. (2017). Textual Treasure Hunting: Using Geocaching to Teach the Art of Close Reading. In Hetland, T. (szerk.), Teaching Literature with Digital Technology. Assignments. Boston \& New York: bedford / st. martin's, Macmillan Learning.

Molnár Gábor \& Gonda Zsuzsa (2018). Digitális annotáció az irodalomtanításban - egy pilot vizsgálat eredményei. Iskolakultúra, 28(5-6), 113-127.

Oláh Szabolcs (2018). Storytelling az üzleti kommunikációban: az irodalmi olvasás elsőbbsége. In L. Varga Péter, Molnár Gábor Tamás \& Palkó Gábor (szerk.), Digitális (szöveg)kultúrák a bölcsészképzésben. 127-147.

Pallo, V. (2017). Text Meets Hypertext: An Online Approach to Teaching Poetry. In Hetland, T. (szerk.) Teaching Literature with Digital Technology. Assignments. Boston - New York: Macmillan. 172-186.

Pethőné Nagy Csilla (2005). Módszertani kézikönyv. Budapest: Korona Kiadó.

Petőfi S. János \& Benkes Zsuzsa (1998a). A verbális szövegek kreatív megközelítése szövegtani keretben I. Iskolakultúra, 8(1), 3-11.

Petőfi S. János \& Benkes Zsuzsa (1998b). A verbális szövegek kreatív megközelítése szövegtani keretben II. Iskolakultúra, 8(2), 47-56.

Smith, C. K. (2017). Remapping World Literature through Multimodality. In Hetland, T. (szerk.), Teaching Literature with Digital Technology. Assignments. Boston - New York: Macmillan. 379-398.

\section{Absztrakt}

A tanulmány a digitális eszközöknek és médiumoknak az irodalomtanításra gyakorolt hatását vizsgálja. A vonatkozó nemzetközi szakirodalom áttekintésében az irodalomolvasás és a digitális kultúra közötti feszültséget és ugyanakkor lehetséges kapcsolódásokat vizsgálja. Bemutatja az irodalomolvasás eltérő kortárs tipológiáit, így Hayles háromosztatú modelljét, a szövegbe belefeledkező és a kritikai olvasás kölcsönviszonyát, valamint a szoros olvasás fogalmának újabb átértelmezéseit a digitális közegben. Ezek az újraértelmezések a nem-szöveges médiaeffektusok szövegként olvasását szorgalmazzák, másfelől nagyobb hangsúlyt fektetnek az olvasás társas és kontextuális jellegére is - miközben a szövegek nyelvi részleteire való odafigyelésről sem feledkeznek meg. A tanulmány második része egy iskolai kísérletet mutat be, amely empirikus adatokkal járul hozzá a kortárs vitákhoz. A kísérletben a diákok kreatív digitális eszközök (gondolattérkép-készítő, kollaboratív szövegszerkesztő, kép- és videoszerkesztő szoftverek) segítségével dolgoztak fel irodalmi műveket. A kísérlet eddigi eredményei azt sejtetik, hogy a kreatív és interaktív digitális módszerek nem eltávolítják a diákokat az irodalmi szövegtől, hanem éppen elmélyíthetik és segíthetik az irodalom megértését. 